https://helda.helsinki.fi

\title{
Placing resilience in context : Investigating the changing experiences of Finnish organic farmers
}

\section{Herman, Agatha}

2018-02

Herman , A , Lahdesmaki , M \& Siltaoja , M 2018 , ' Placing resilience in context :

Investigating the changing experiences of Finnish organic farmers ' , Journal of Rural

Studies , vol. 58 , pp. 112-122 . https://doi.org/10.1016/j.jrurstud.2017.12.029

http://hdl.handle.net/10138/310808

https://doi.org/10.1016/j.jrurstud.2017.12.029

cc_by_nc_nd

acceptedVersion

Downloaded from Helda, University of Helsinki institutional repository.

This is an electronic reprint of the original article.

This reprint may differ from the original in pagination and typographic detail.

Please cite the original version. 
This manuscript has been accepted for publication in Journal of Rural Studies, 2018, 58, 112-122.

\title{
Placing Resilience in Context: investigating the changing experiences of Finnish organic farmers
}

\author{
Agatha Herman, Cardiff University \\ Merja Lähdesmäki, University of Helsinki, Ruralia Institute \\ Marjo Siltaoja, University of Jyväskylä
}

\begin{abstract}
Understanding how farmers are resilient is critical for effective government and individual management responses in an increasingly uncertain world. Through an inter-temporal focus on Finnish organic farmers, we explore changing identities, attitudes and practices, and reflect on ramifications for farming resilience. Despite the essentialising binaries perpetuated by discussions of conventionalisation and bifurcation in the organic movement, organic production systems are, and always have been, heterogeneous. This paper offers a nuanced analysis of the fluctuating and mixed practices and identities that compose the sector. Considering the experiences of both 'pioneer' and 'contemporary' organic farmers highlights the multiple, changeable and, critically, contextual nature of strategies for resilience at the farm level. It emphasizes too the fluid, hybrid and strategic subjectivities of the organic producers themselves that are always dependent on the demands of particular contexts; therefore, although 'best practices' may offer possible pathways for action, varying spatialities and temporalities cannot be homogenised into an ideal type resilience. 2
\end{abstract}

\section{Introduction}

Although discourses around organic agriculture have moved beyond its initial, rather particular ecological morality (Fouilleux and Locanto, 2017), the narratives and practices of its production and consumption remain widely positioned as a solution to the problems associated with conventional agri-food; an alternative to industrial and productivist agricultural models; an opportunity to (re)connect and (re)embed in local socioecologies; and a way to achieve healthy soil, people and environment (Clarke et al., 2008, Fouilleux and Locanto, 2017, Läpple and Van Rensburg, 2011). However, such utopian perspectives serve to enact an unproductive and overly structured analysis of conventionalisation and bifurcation in which the organic movement is separated into small/local/authentic and large/national/commercial operations (Guthman, 2004, Halberg et al., 2006, Padel, 2008, Milestad and Darnhofer, 2003, Ilbery et al., 2016, Lobley et al., 2013). Following Campbell and Rosin (2011), we agree that this masks the evolution of organics as a participatory and negotiated process composed of a diverse interplay of spaces and practices. Organic systems - despite increasing institutionalisation through standards bodies and certifiers (Fouilleux and Locanto, 2017) - remain heterogenous and regionally uneven (Campbell and Rosin, 2011, Ilbery et al., 2016), and the complex ethics 
involved preclude an easy mapping onto the scales of local, regional and national, which are oft-referenced in debates around organics (Clarke et al., 2008).

In this paper, we contribute to calls for a greater understanding of the contested worlds and complex farmlevel dynamics of organic agriculture (Campbell and Rosin, 2011, Rosin and Campbell, 2009) through a focus on the experiences of Finnish organic producers. Finland presents an interesting empirical arena because of its unique position, within the European context, as a recently developed industrial and urban nation with a consequently deep and persistent peasant culture, and widespread connections to rural spaces and identities (Buciega et al., 2009, Silvasti, 2003a). While the state continues to play a significant role in ensuring the continuity of agriculture, lancu (2012) argues that the competitiveness of Finnish farming also depends on the introduction of hi-tech innovations and the latest agricultural knowledges, which, given its recent rural heritage, establishes Finland as an interesting negotiation between traditional and modern techniques and ideas; organics is a key part of this mix, becoming part of Finland's brand strategy in 2010 (Evira, 2014). Furthermore, the Finnish focus serves to broaden the empirical scope of rural research more generally, which to date has been highly UK and US-centric (McDonagh, 2012).

Rather than judging whether different practices, discourses, motivations or scales within Finnish organic agriculture are good, bad, conventional or alternative (Gibson-Graham, 2008), here we take a more contingent and open approach to explore and analyse the local negotiations and relations that facilitate, and are facilitated by, the global development of a stable organic market and reduced sectoral uncertainty (Rosin and Campbell, 2009). Nonetheless, as Milestad and Darnhofer (2003: 84) comment 'farmers have always lived in changing environments - politically, economically and ecologically - where surprise and structural change are inevitable'. We therefore take a longitudinal approach to investigate the multiple and varying engagements through which Finnish organic producers have struggled to maintain their livelihoods, legacies and identities in an evolving and volatile agricultural sector. We draw on the experiences of both early adopters, who converted in the 1970s and 1980s and who are now largely retired, and more recent converts who became organic between 2008 and 2013. While, as Läpple and Van Rensburg's (2011) Irish study found, the two groups did demonstrate different characteristics and motivations, we are more interested in the fluid and hybrid subjectivities of both groups that the empirics uncovered.

Resilience - as the 'ability to persist in an uncertain world' (Perrings, 1998: 221) - offers a useful conceptual framework to understanding farmers' experiences of, and practices in relation to, processes of change. After all, understanding how individuals and communities negotiate unpredictable environments is critical for management responses at both the state and farm level (Maclean et al., 2014). Although the intertwining of the social and ecological within systems has long been recognised in resilience literatures, Adger (2000) argued that the concept had not been effectively brought across the disciplinary divide from its origins in 
ecology and that its very transferability was questionable. This argument persists with Maclean et al (2014) noting that the inherent challenges in bringing together the social and ecological have meant that a distinct knowledge gap with respect to the normative aspects endures while Olsson et al (2015) argue against the inappropriate and unifying extension of natural science concepts to society. Despite the growing research into social resilience (see Aldrich and Meyer, 2015, Cuthill et al., 2008, Dale et al., 2008, Krøvel, 2014, Maclean et al., 2014, Magis, 2010, Mason and Pulvirenti, 2013, Berkes and Ross, 2013) more work is therefore needed to further conceptualise this important but under-theorised concept.

Cote and Nightingale (2012: 475) argue that using ecological principles to analyse social dynamics masks the key normative questions 'resilience of what and for whom?'. Here, we draw on Milestad and Darnhofer's (2003) and Darnhofer et al's (2016) framework of farm resilience to reflect on a socio-agricultural resilience that acknowledges all the entangled economic, social, cultural, political and environmental interconnections involved in constructing and performing a farm. While it is beyond the scope of this paper to fully explore this holistic nexus, we engage with four key and interlocking themes - building social capital, market innovations, governance engagements and family working - to explore the multiple and changeable strategies for resilience at the farm-level. By doing so we respond to Cote and Nightingale's (2012) call to stop abstracting resilience, and instead situate it within the heterogeneous, mediated and power-laden socio-cultural relations and processes that govern human adaptations to change. We engage with producer experiences at the local scale since it is through everyday practices that the latter encounter risk (Komino, 2014) and so operationalise resilience.

In this paper, we first critically reflect on resilience through a discussion of agricultural and farm resilience, and organic production literatures before outlining our research context and methods. We then move on to explore the changing cultures of Finnish organic production; organic farmers are not a homogenous grouping because since 1990, and particularly in the dairy sector, the movement has mainstreamed, becoming recognised as a key strategy to maintain economic profitability while meeting EU environmental targets (MMM, 2007, SGPFS, 2010, MMM, 2011). Taking a comparative approach to the changing strategies of both early adopters and recent converts, we develop a nuanced understanding that moves beyond the conventionalisation and bifurcation debates. Through a focus on social networks, economic changes and skills development we analyse the varying and multiple contexts through which farm resilience is performed. We conclude by critically reflecting on the hybridity and dynamism of the farmer subjectivities that highlight the spatial and temporal contextuality of resilience, which is - as both Anderson (2015) and Olsson et al (2015) argue - better understood not as an universal and unifying concept but as pluralistic resiliences.

\section{Socio-Agricultural Resilience}


Social resilience is the process by which 'individuals, communities and societies adapt, transform and potentially become stronger' (Maclean et al., 2014: 146) when faced with challenges. Central to this is the fact that change, not stasis, is the constant because social memory and learning ensure that a social system can never revert back to an 'original' state (Folke et al., 2003, Magis, 2010). For Howell (2015) this is because resilience is fundamentally about 'enhancement' but critics argue it is difficult to reconcile this ambiguity, with resilience seemingly about both change and resistance to change (Olsson et al., 2015). As Berkes and Ross (2013) note a system may also have various stable states, which may not all be desirable; this emphasizes the multiplicity, uncertainty and contingency of social resilience, which belongs in 'a real world that is messy, complex and often unpredictable' (Krøvel, 2014: 64).

Resilience, like other 'buzzwords', has been dismissed by critics as ambiguous, depoliticised and disengaged with justice issues (Brassett et al., 2013, Diprose, 2014) but, while acknowledging its limitations in terms of definition and quantification (Anderson, 2015, Olsson et al., 2015), we agree with proponents who argue that it remains a useful tool to engage with experiences of unpredictability and processes of change (Coward, 2015, Wilson, 2015, Cote and Nightingale, 2012). Despite these challenges, a number of common themes emerge in the literatures that allow us to begin to conceptualise how social resilience may be practised. Communication, co-production/participation, active agency, social capital, resources, learning and social memory, attachment to place, social networks, local knowledges and equity (Aldrich and Meyer, 2015, Berkes and Ross, 2013, Krøvel, 2014, Magis, 2010, Norris et al., 2008, Wilson, 2015, Elms, 2015, Uscher-Pines et al., 2013) emerge repeatedly in the literatures, highlighting the multidimensional nature of social resilience as well as hinting towards the power and social relations it must negotiate (Mason and Pulvirenti, 2013). Maclean et al (2014: 146) offer a useful synthesis, arguing that the key attributes that shape 'the way in which individuals, communities and societies adapt... when faced with environmental, social, economic or political challenges' are: (i) knowledge, skills and learning; (ii) community networks; (iii) people-place connections; (iv) community infrastructure; (v) diverse and innovative economies; and (vi) engaged governance. Therefore:

'Resilience thinking offers a useful framework to analyse agricultural issues because it focuses attention on the unpredictable nature of disturbances and management options that accommodate such unknown threats' (Hammond et al., 2013: 317, emphases added)

To date, research on agricultural resilience has focused predominantly on economic, policy and management issues (see Maleksaeidi and Karami, 2013, Ranjan, 2014, Hammond et al., 2013, Björklund et al., 2012, Lin, 2011); for example, Hammond et al's (2013) study analyses farmer responses to disturbances such as climate change, flooding and fluctuating energy costs. They note that individual commitment and farming in an 
historically consistent manner are important components supporting farmers' persistence. The place of the farm itself forms an integral part of farmer identity, which connects into a responsibility to the decisions and wishes of predecessors (Lähdesmäki and Matilainen, 2014). Indeed, Burton (2004: 206) argues that the nature of farming means that the farmers 'are representing not simply their own identity but those of their families past, present and future' and so the land is both a working environment and a 'self-portrait'. This reminds us that we need 'to look outside the farm and inside the farmer' (Ahnström et al., 2008: 43) when considering the factors developing and supporting social resilience, because we must acknowledge both the internal and external factors, which shape how a farm is experienced and practised (Gray, 1996). After all, the farm scale is always embedded within larger nested systems (Hammond et al., 2013), with farm resilience enabled and constrained by what happens at both the micro and macro scales (Darnhofer, 2014). This emphasizes the potential for significant heterogeneity within farming networks (Maleksaeidi and Karami, 2013, Ranjan, 2014) and reminds us of the empirically various nature of resilience itself. Anderson (2015) warns of the dangers of obscuring the uneven spatialities and temporalities of different formations of resilience, which echoes questions as to whether it is possible for farmers to attain resilience in multiple dimensions (Ranjan, 2014) and whether an individual can be resilient in one context or to one stressor but not others (Berkes and Ross, 2013).

Farming typically consists of multiple regulatory, environmental, economic and socio-cultural stressors; how these are addressed are strongly shaped by the local contexts and discourses defining what constitutes 'good' farming, which can have significant impacts on the mental health, and so personal capability, of the farmer (Burton, 2004, Hansson and Lagerkvist, 2012). Mental health has formed a significant part of the existing research into agricultural resilience and highlights the importance of social capital, community, learning, local knowledge and resources (Greenhill et al., 2009, Hunt et al., 2011, Fraser et al., 2005, Berry et al., 2011); more recent work continues these themes through discussions of the challenges in balancing continuity and change in farm succession strategies (Forney and Stock, 2014). Nonetheless, the use of ecological principles in these social systems has often abstracted social resilience from its context and adopted an individualistic approach to agency, resulting in an instrumental, power-less, depoliticised and conservative approach to social change (Cote and Nightingale, 2012, Cleaver and Franks, 2005) that brackets agency and ignores the dynamics of conflict (Olsson et al., 2015).

As Darnhofer et al (2016) note research on agricultural resilience tends to focus on either the biophysicalstructural or social-actor dynamics; while each perspective has its benefits, Darnhofer et al (ibid) argue that a relational approach better conceptualises change, and the contingent and contradictory nature of resilience. After all, resilience is not a state of being but is emergent and grounded in interactions across multiple spatial and temporal scales (Darnhofer, 2014). For Darnhofer et al (2016: 117) 'the farm as it is now, 
is but a stabilised moment in a process of continual becoming' and so resilience in agriculture is best explored through a focus on farming rather than the farm. This better encapsulates the intrinsic sense of performativity and potential-to-be-otherwise with farming resilience 'continuously remade in interaction' (ibid: 118). Resilience is therefore about the processes and conditions that make certain relations possible and constrain others, which helps us to understand and analyse how opportunities, alternatives and futures are imagined and operationalised to transform the farm-space. Farming resilience emerges as fundamentally contextual since 'a farm is unlikely to be resilient per se, but can be resilient given its current ecological, economic and political context' (Darnhofer et al., 2010: 194).

Darnhofer et al's (2016) relational approach has informed our understanding of the contextual, emergent and unfinished nature of resilience, which emerges in our empirics as we consider some of the market, social, institutional and familial relations that shape the Finnish organic terrain. The particular experiences and fluid subjectivities that emerge emphasize the contextuality and dynamism of farming resilience. While we acknowledge the biophysical and more-than-human relations that are co-constitutive in governing farming spaces (Dwiartama and Rosin, 2014, Herman, 2016), our empirics focus on the perspective of the human actors. This enforces a response to those key normative questions posed by Cote and Nightingale (2012), which we consider to be critical to thinking about the power relations within these contingent and dynamic farm spaces. Who is resilience for and who is benefiting from any particular 'resilience enhancing' strategy?

Here, we position the scale of analysis (or the 'who') as the farm but there are clear difficulties in bounding a farm system (Olsson et al., 2015) - how can you untangle the capability of the farm to persist in an unpredictable environment from that of the farmer(s), workers, buildings, animals, plants, soils, markets, retailers and regulators, amongst others? Clearly, then, the resilience of the farm as a particular stabilised moment in time and space (Darnhofer et al., 2016) is grounded in the combined adaptive capabilities of all the different elements of this system. We are not positioning 'the farm' as a normative concept and so here farming resilience is simply the practices and relations through which an area of land and its buildings, that are used for producing crops and/or animals, continues to produce crops and/or animals. By not demanding a certain form for the land, crops grown, buildings constructed or animals reared, space is made for both continuity and change, while retaining the ability to distinguish between them (Olsson et al., 2015).

How then is farming resilience enhanced? As might be expected in organic farming, the discourse of organics itself plays a significant role in shaping the practices and experiences of its producers (Milestad and Darnhofer, 2003, Ilbery et al., 2016), particularly through the regulated and audited requirements of organic certifiers such as Evira in Finland. Organics is understood as a non-industrial relationship between producer and nature (Halberg et al., 2006), which offers a more ecologically sustainable alternative to conventional farming methods through controlling the inputs into the farm system. Sutherland (2013) reflects on the social 
stigma initially attached to organics, with early pioneers tending to be idealistic and well-educated with limited farming experience but connections beyond the locale. This meant that the social stigma and ostracization from the local farming community, resulting from conversion, acted as less of a deterrent than to more established farmers (Morgan and Murdoch, 2000). In Silvasti's (2003a) Finnish research, conventional farmers continued to view organics with suspicion, arguing that its lower productivity and reliance on price premiums was immoral and did not constitute 'real' farming. Siltaoja et al (2015) further showed how such stigmatization required the adaptation of conventional farming vocabulary (farm size, production volumes, machinery) into the organic farming discourse. While organic farmers have always evaluated their success in different terms to their conventional counterparts (Reimer et al., 2012), arguably the inability of organics to be assessed under traditional, hegemonic social scripts of 'good' farming was a barrier to conversion (Burton, 2004). However, the combination of economic and environmental benefits are changing opinions with financial pressures becoming a key factor in motivating organic conversion because it is increasingly recognised as a viable and attractive business opportunity (Sutherland, 2013).

Milestad and Darnhofer (2003)contend that organic agriculture offers a combination of environmental, social and economic benefits, and we have used Maclean et al's (2014)framework to consider a selection of the key elements of organic production as discussed in the literatures (Table 1). Understanding thesecentral values, structures and relations of organics begins to open out some of the key strategies that allow farms to successfully navigate change in this sector.

Knowledge, skills and learning

Offers scope to learn from peers and to draw on specialised knowledge networks of researchers and producers.

\section{People-Place connections}

Grounded in tacit, experiential knowledge fostering the understanding of natural cycles and practical skills; values indigenous knowledges and local adaptations; positions farmers to be 'knowing agents'.

Preserves landscape values; supports the continuation and development of local knowledges; enhances livestock welfare.

Supported by a conversion grant; offers opportunities for personal capacity-building; CAP reform; local, slow and farmers markets. 


Diverse and innovative
economies
direct marketing; promotes local and regional supply chains;
offers premium pricing opportunities; cost-saving in terms of
inputs; fosters diverse, balanced and interactive farm
activities; promotes local, rural development.

Engaged governance

Farmers able to exercise more autonomy and control; shared values between producers' support 'buy in' to the regulatory system; reduced external inputs; democratic institutions

Table 1 Resilience Enhancing Opportunities Offered by Organic Agricultural Systems. Sources: Morgan and Murdoch (2000), Milestad and Darnhofer (2003), Halberg, Alroe et al. (2006), Padel (2008), Sutherland (2013)

The conventionalisation trend in organic agriculture has been under discussion since organics mainstreamed as a globalised system of regulated trade (Halberg et al., 2006, Lobley et al., 2013). Increased demand led to larger farms and specialization, which critics argue decreases farmresilience by increasing the external inputs and environmental impacts (Milestad and Darnhofer, 2003). Furthermore, with the increased hegemony of certification and influx of more utilitarian motivations (Padel, 2008), an 'organic lite' began to emerge (Guthman, 2004)since 'growers have little incentive to incorporate an ideal practice when an allowable one will suffice' (Milestad and Darnhofer, 2003: 91). The international organic movement remains divided on how to deal with these challenges (Halberg et al., 2006)but there are general calls for a more supportive regulatory environment and a need to establish organics as a more distinctive alternative to conventional, industrial agricultural approaches (Morgan and Murdoch, 2000). Established producers commonly fear that those converting will not share their values and so change the way organics is both practised and perceived. However, Padel's (2008)study argued that the differences that did exist were related to the length of involvement in organic agriculture, suggesting that producers tend to become 'more organic' over time, a process which can be supported through ensuring positive interaction and communication of values within organic producer networks. We explore this conventionalisation and bifurcation of the movement through discussing the multiple and fluid resilience strategies of both early adopter and more recently converted organic producers.

\section{Research Context and Empirical Data}

This research is based on interviews with 24 organic farmers. The purposeful selection (Patton 2002) of the interviewed farmers was based on the following criteria. First, all of the interviewees had farmed 
conventionally before their conversion to organic agriculture. Previous experiences of conventional farming were considered to enhance farmers' ability to assess their organic farming careers, thus increasing the profundity of the empirical data. Second, we were particularly interested in cultural variations over time and so focused on farmers representing two distinct time periods: those who converted between 1973-1989 (prior to governmental support) and 2008-2013 (post-global recession). We interviewed 11 farmers from the earlier group, who we refer to as 'pioneer organic farmers' (POFs), contacting them through organic farming associations, and 13 of the more recent converts, 'contemporary organic farmers' (COFs), who were contacted through official farmer registers. We intend this distinction simply as an identification device, acknowledging that these groupings are neither exhaustive nor homogenous. As such we are not trying to 'impose a system on an inherently untidy experience' (Douglas, 2002:5) but this identification highlights both the intra-and inter-group commonalities and differences, which allows for a more nuanced and accessible engagement with the changing practices of farming resilience. Finally, our interviewees also represent a range of different production systems that reflects the agricultural diversity of Finland (Table 2). The interviewed organic farmers were also geographically dispersed as they were located in four different regions. Our selection of interviewees aimed to foster the credibility of the empirics rather than representativeness (Patton, 2002) because, following Miles and Huberman (1994), in order to understand and capture the contextuality of the experience of conversion from conventional to organic farming, we needed to explore different instances from different moments in different places and with different people.

\begin{tabular}{|c|c|c|c|}
\hline & Year of Conversion & Cultivated Area (ha) $)^{1}$ & Production System \\
\hline \multirow{11}{*}{ 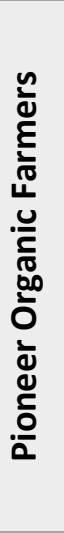 } & 1970s & n.a. & Dairy \\
\hline & 1973 & 31 & Sucklers; vegetables \\
\hline & 1975 & 17 & Arable \\
\hline & 1977 & 18 & Arable \\
\hline & 1980 & 120 & Arable \\
\hline & 1984 & 20 & Arable \\
\hline & 1986 & 10 & Arable \\
\hline & 1987 & 12 & Arable \\
\hline & 1988 & 15 & Arable \\
\hline & 1988 & 60 & Sucklers; eggs \\
\hline & 1989 & 14 & Arable \\
\hline \multirow{8}{*}{ 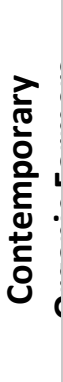 } & 2008 & 21 & Sheep \\
\hline & 2008 & 230 & Sucklers; beef cattle \\
\hline & 2009 & 110 & Dairy \\
\hline & 2009 & 30 & Pigs \\
\hline & 2010 & 38 & Arable \\
\hline & 2010 & 40 & Sucklers \\
\hline & 2010 & 45 & Sucklers \\
\hline & 2010 & 20 & Arable \\
\hline
\end{tabular}

\footnotetext{
${ }^{1}$ The average cultivated area in the Finnish farms is 40.7 ha. Finnish agriculture is almost exclusively based on family farms: in $2014,87 \%$ of the farms receiving support were privately owned and $11.3 \%$ were owned by heirs and family companies and corporations (Väre 2015). All the interviewed farms in this study were family-owned.
} 


\begin{tabular}{|c|c|l|}
\hline 2011 & 100 & Dairy \\
\hline 2011 & 50 & Sucklers \\
\hline 2012 & 20 & Sheep; eggs \\
\hline 2012 & n.a. & Sucklers \\
\hline 2013 & 55 & Pigs \\
\hline
\end{tabular}

Table 1 Interviewee Details

The historical and cultural context for the organic conversion of POFs and COFs -as well as the agricultural challenges and disturbances experienced -differs greatly. Early exponents of organic farming were commonly motivated by issues around agri-chemicals, particularly relating to soil and human health, and their sustainability(Yliviikari, 2016).The global oil crisis in the 1970s presented a key shock in Finland, and elsewhere, through highlighting conventional farming's increasing dependency on synthetic fertilizers, manufactured using imported petroleum, which forced some to re-evaluate their farms relations and practices. Organic conversion in this period was therefore grounded in ideas of self-sufficiency as well as being part of a growing, societal trend for environmental care more broadly (Heinonen, 2004). Still, during the 1980s, organics remained marginal, covering less than $0.1 \%$ of Finland's cultivated land. Nevertheless, several organic farming societies were formed during this period (Mononen, 2008), which went on to found the Finnish Association for Organic Farming (FAOF) as their umbrella organization in 1985; this introduced the first national standards and inspection system in 1986. At this point the government began to support advisory work, education, training and research in organic agriculture, introducing the conversion support scheme in 1990 and a farming subsidy in 1995.

Since joining the EU in 1995, and becoming part of the global agri-food system, Finnish agriculture has undergone major structural changes including increasing farm size, specialization and demands for efficiency as farmers attempt to survive in a fiercely competitive food sector (Väre, 2015). By 2008, input prices, particularly for energy and fertilisers, had for some years been rising faster than commodity prices, resulting in decreasing profitability (Rantala and Tauriainen, 2015). Farmers are increasingly expected to operate as innovative and risk-taking business owners, rather than 'merely' food producers (Vesala and Vesala, 2010, Vesala and Peura, 2005), with the neoliberal discourse of entrepreneurialism encouraging farmers to take personal responsibility instead of relying on state interventions, protection and subsidies (Pyysiäinen, 2011). For the COFs, organic conversion offered a strategy to secure the long-term economic and environmental viability of their farms (Kallinen et al., 2012). Accordingly, organic farming has gained a foothold and by 2010 accounted for 4200 out of the total 63870 holdings, or $10 \%$ of Finland's cultivated land area (Evira, 2014, Eurostat, 2013).

Our in-depth semi-structured interviews varied from 45 to 90 minutes long, and were all conducted between May and September 2014 and transcribed verbatim. The interviews were approached as flexible conversations in which we discussed key themes (including farming history, motivations for conversion, 
experiences of the conversion process, farmer identity and future expectations) as they came up in conversation while remaining responsive to other issues raised by the farmers themselves (Legard et al., 2003). Thus, similar to narrative or bibliographic interviews, our interview technique aimed to allow the organic farmers to reflect upon and recall episodes of their organic farming careers by not imposing our theoretical framework on the interviewees (see Rosenthal, 1993, Wagner and Wodak, 2006). The empirical data was analysed using a qualitative content approach, which focused on the thematic identification of 'social resilience' and the ways in which this was constructed in the interviews. The data analysis was therefore an iterative process between our empirical data and Maclean et al's (2014)framework of social resilience, which enabled us to analyse how change was perceived and confronted by the farmers. Although all interviews were conducted in Finnish -the native language of two of the authors and the interviewees - quotes from the original interviews have been translated into English to ensure the transparency of our empirical discussion.

\section{4 .Becoming Resilient in Finnish Organic Production}

Farming resilience is contextual, multiple and performative; we reflect here on some of the different strategies pioneering and more recent converts have adopted in order to persist in the face of industry and global uncertainty and transformation. The different contexts surrounding each group's conversion shape their norms, relations and experiences, and we explore what these temporal changes mean for the strategies and structures that have so far contributed to their farms continuation, and what this means for farming resilience more broadly.

\subsection{Building Social Capital}

Finnish agriculture during the 1980s can best be characterized by a productivist ideology, with an emphasis on state-supported agricultural production based on intensive farming methods and biochemical applications. By giving up artificial fertilizers and other chemicals, the POFs were clearly differentiated from the agricultural zeitgeist emphasizing efficiency and production targets. Hegemonic productivist discourses were also strongly reflected in contemporary conceptions of a 'good farmer', which was defined by the physical appearance of the crop and yield (Silvasti, 2003a). Organic farming confronted these ideals and established alternative criteria for 'good farming', grounded in selfsufficiency, health and chemical-free methods (Reimer et al., 2012, Stock, 2007b). This challenge to the dominant discourses meant that the decision to start organic farming often had noticeable social impacts at the personal level, affecting farmers' social status and relations. POFs aroused wonder, scepticism and even ostracism from their local farming communities (Duram, 2005, Stock, 2007a, Siltaoja et al., 2015), which in turn meant that there was often very little dialogue between organic and conventional farmers 
because they were relying on different information sources and were part of very different social networks (Rigby et al., 2001). The narratives of our POFs echo these discussions with many of the farmers reflecting on their post-conversion marginalisation, noting that they subsequently received very little support from their conventional neighbours:

'Well, my neighbours didn't consider me as a farmer at all. They didn't agree to talk with me. And I guess local farmers were trying to avoid me. They thought that I was engaging in some sort of witchcraft'(POF A)

However, this social marginalisation motivated the POFs to actively extend their social networks beyond the spatial borders of their local community. Here, we follow Valante (1996)in defining 'social network' as the pattern of friendship, advice, communication or support, which exists among members of a social system and establishes a sense of community. In this instance, networking with other early adopters became an essential source of engagement and support for the POFs and, even though this network was geographically scattered and rather small in number, those interviewed characterise it as both tight and active. In some cases, this network building even extended beyond the national borders as the POFs also searched internationally for peer support. According to Padel (2001)this kind of informal network building is characteristic of innovators, for whom it is important to stay connected around a common theme (Curry et al., 2012)despite, as in this case, often considerable distances. This is demonstrated in the recollections of one POF who started farming biodynamically in the late 1970s, when this production method was very unusual in Finland. He had first encountered biodynamics in farming books and magazines when he was actively seeking solutions to address soil deterioration. However, it was the social networks of biodynamic farmers, and the consequent support and encouragement, which strengthened his commitment to this alternative farming method:

'I found the idea of biodynamic farming by reading some books on the topic and a little later I become acquainted with the biodynamic association. [...] For me, belonging to the biodynamic association was really important -I was a board member-because through the association I had contact with other like-minded farmers [...] It was an important means for advice and support. And, of course, the visits to farms abroad were crucial. Our association made several visits to farms in Germany and Sweden and so on. Knowing the foreign biodynamic farmers, it was important for me' (POF B)

Social networks proved critical because they enabled identification with a defined group as well as practical information exchange. Given the incipient nature of organic production in Finland in the 1980s, there was limited information and data available and so the POFs usually learned the best cultivation strategies through trial and error. This reflects an entrepreneurial spirit in the search for solutions 
to their practical problems, which some took further in proactive efforts to conduct cultivation experiments and develop farming equipment in order to advance organic production techniques. This self-belief and agency, together with the capacity to learn, develop skills and knowledge, and engage in social networks, are highlighted by Maclean et al (2014)and Berkes and Ross (2013)as critical components of social resilience, which for our POFs were intertwined. Experiential and co-learning were key as they developed skills and understanding through experimentation and sharing knowledge with others in their social networks (see Kummer et al., 2012, Curry et al., 2012). Accordingly, the POFs often invested a lot of their resources -both time and money-in enhancing their knowledge of organic farming, which, critically, was something that they were also willing to share with others. Therefore, these often informal networks became an essential source of social capital and bottom-up innovation as they served to build a sense of community, disseminate information and so increase the knowledge level among the organic producer body as a whole. As one POF summarised:

'I have disseminated a lot of information which has benefited all, including myself. I think that the collaboration between the farmers has been crucial for the development of the professional skills of organic farmers'(POF A)

Within this, active engagement at a personal level was highlighted as essential if producers were to really benefit from the information, tools, support and strategies available, as one POF commented when describing the learning process during his organic conversion:

'There weren't any official organic advisors or anything else either. You had to figure everything out by yourself or discuss with the other farmers in your social networks. I actively took part in the activities of Ekoviljelijät [Association for Ecological Farmers] and there was a lot of discussion there. We also visited each other's farms in order to learn new methods. I guess that I have visited the majority of organic farms back then' (POF D)

Even though knowledge sharing and learning from each other's experiences was an important strategy for the POFs, it is noteworthy that practical collaboration was rare. The small number of farmers, combined with their disparate geographical spread, made collaboration in terms of co-ownership or the sharing of farming equipment impossible. However, in instances where there had been collaboration with neighbours prior to conversion, after turning organic these connections ended with our POFs suggesting that the differences in farming methods raised too many obstacles to easy and effective collaborative relationships. Building social networks and contacts with other organic farmers retained its critical role for the COFs but, while the POFs were forced to establish and extend their networks beyond the local farmer community, the rise in numbers of organic producers means that more recent converts usually found their social reference groups nearby. As with the networks of the POFs, these offer advice and support as well as an 
essential comparative function, which emerged as critical in the COFs decision to convert. The COFs had often evaluated their chances of successfully farming organically by comparing themselves with existing organic farmers in the locality-the 'neighbourhood effect' identified by Bjorkhuag and Blekesaune (2013)in the diffusion of organic production in Norway. Being able to see that another producer -within a very similar context -was succeeding often gave uncertain farmers the final encouragement. For the following COF, both economic reasons and the comparative insights gained from engaging in peer networks were positive contributors to his conversion decision:

'And for me, a further incentive for organic farming was one of my relatives who has a farm nearby and has been farming organically for almost fifteen years. He has sucklers too, the breed is different than ours but he has a similar cowshed and... I have followed how things have been done there and I have watched how they have succeeded with cultivating the fields without chemicals and seen that the fields are not so bad looking. Everything has worked well there and I think that it has been the most important incentive for me to start organic farming. I guess that when you see that someone else has succeeded in doing something, you easily start thinking that you could also do it' (COF L)

The social relationships between neighbouring organic farmers provided opportunities for collaborative learning and sharing of equipment that were unheard of for our POFs. Several of the COFs had started organic farming at the same time as another farmer, and so they were working their way through the process together, able to discuss practices, ideas, challenges and opportunities. Therefore, after converting to organic, many of the COFs commented on the improvement in their relationships within the local farming community; in some cases, this had resulted in intensive collaboration in everyday farming practices as well as collective purchases, subcontracting and co-marketing of products.

\subsection{Engaging with Governance Institutions}

Through the connections established in the initial, niche social networks, official organisations and industry infrastructures began to emerge and many of our POFs were active in establishing local and regional associations, with the express aim of promoting awareness of, and enthusiasm for, organics in Finland's agricultural regime. These new, more formal associations also gave the POFs an opportunity to shape how the discourse of 'organic' was understood and put into practice, an opportunity extended when FAOF was established in 1985. This organisation's mission was to increase the official status of organic farming amongst political decision-makers and consumers: 
'We were the ones to create the framework for organic farming in Finland. For example, I think that it was a notable event in the mid-1980s when we established the association for organic production here in our region. I was the first chairman of the association' (POF E)

Therefore, in addition to their benefits in terms of support, learning, knowledge transfer and socialisation, the early social networks and organic associations also offered a means for POFs to engage with the political discourses around agriculture, to express their concerns for conventional production, to shape what 'organic' meant in the Finnish context and to advocate for more environmentally responsible practices.

It was clear that many of the COFs appreciated the occupational challenges of organic farming practices. Many felt that they already knew conventional farming methods, and so converting to organic provided an opportunity to challenge themselves and start learning something new. These statements echo previous research, which has shown that the realization of professional and personal potential has gained importance as a motivation for conversion (Michelsen, 2001). Nonetheless, it must be noted that not all aspects of organic farming were welcomed as agreeable learning opportunities; for example, the increased paperwork was commonly described as a time-consuming, challenging and 'repulsive' task. Furthermore, whereas for the POFs innovative experiments and the development of new farming techniques played an important role in their learning processes, for the COFs this experimentation was replaced by a more institutionalized way of learning as organics shifted from a divergent to compatible mode of interaction with the mainstream agricultural regime in Finland (Ingram et al., 2015). Now an organic farming course is a mandatory prerequisite for receiving organic subsidies and provides each new organic farmer with a basic, standardised framework for organic farming. Similarly, the increasingly important role of organic advisers was highlighted:

'The organic adviser visits our farm always in the spring. We discuss the cultivation methods and the paperwork, and he gives some tips concerning what kind of grains I should use in order to get a proper yield. So we have utilized the expertise of the advisers because they see a lot of different farms and they know what the best methods to farm organically are. And the advice they have given us has proved to be very useful. We will certainly use their assistance also in future' (COF K)

Innovative experimentation as a learning method is further restricted by the fact that, today, organic farming is strictly regulated and monitored by government. Thus, while the plausibility and reliability of organic farming is protected by detailed certification and accreditation systems, the ownershipof the process of defining organic farming has moved from the hands of farmers to governments (Vogl et al., 2005). As Ingram et al (2015)reflect, the diffusion of what was previously a niche production strategy into the mainstream can 
be disempowering particularly for 'idealistic' producers (Lobley et al., 2013) who may perceive the movement's values and ambitions to have been diluted by regime alignment. Similarly, strict regulation and the consequent paperwork of organic accreditation are perceived to limit the individual autonomy of farmers:

'Well the authorities question and suspect our work all the time. I guess that all the organic inspectors consider us farmers like criminals until proven otherwise. So all I have to do is to prove my innocence when the inspector visits the farm. For example, during the last inspection, I really felt like a major criminal. The inspection lasted for almost eight hours even though back then I had fewer than thirty hectares farmland and you would think that it wouldn't take much time. But no, every corner was snooped in case there would be some forbidden inputs. Even though I knew that I had done everything by the book, I started to feel anxious' (COF J)

While the benefits of regulations in terms of setting minimum requirements from raw material to final product, managing the risks and so maintaining the status of organics were recognised (Kottila and Rönni, 2008), the farmers perceived the regulations as undermining the local knowledge that they themselves have on sustainable farming methods. Furthermore, as the regulations on organic farming are often perceived as obscure, and their interpretation is believed to vary between different authorities, the increasing amount of regulation itself brings about a new kind of threat to the continuation of the farms as organic.

\subsection{Working with Family Values}

The decision to adapt to a challenging and uncertain environment by switching to organic farming connects into long-standing discourses of the 'peasant farmer' in Finland (Silvasti, 2003b), which have established a strong sense of personal and moral responsibility for farmers to take care of their farms. This is driven by the need to maintain continuity, and so the viability of the enterprise, which is achieved through keeping up with agricultural and technological progress, which in turn leads to changes in farm practices, spaces and relations (Silvasti, 2003a). However, perhaps equally as important as the viability of the enterprise is its legitimacy as a 'good' farm, and hence by extension the producer as a 'good' farmer. It is interesting to note that, for the COFs, their articulation of this moral duty required the loss of the traditional, conventional farming practices that had been learned from their parents. In turn, this had caused some disagreements within the family with parents in particular being sceptical and reluctant to agree to such a radical departure in praxis (see Duram, 1999, Schneeberger et al., 2002). Thus, the moral implications of farming decisions and how to address them were a part of resilience strategies: 
'When I started organic farming, my father stated that: "Well, now the shutdown process of this farm has started". It was his view on organic farming. He just couldn't see that this kind of farming method would be a successful one' (COF F)

In contrast, for many of the POFs, their capacity to operate outside of conventional agricultural wisdom, as well as their decision to convert, was grounded in their family history -with their skills and attitudes emerging as inter-generational:

'My father qualified as an agronomist in the 1920s and back then, farming was very ecological in Finland and my father had... well I guess he passed me the old ideas of appreciating the manure as an important input in farming, not a waste. The general view was, you see, that manure is waste and it should be disposed rather than used in the farming' (POF E)

It was common within our group of POFs, for those with farming backgrounds, to have come from relatively extensively farmed systems in which the usage of chemical inputs was rare. As with most farming children, these POFs had been socialised early into the working life of the family farm and so the first farming techniques they learned had similarities with, if not the explicit ideology of, organics. Therefore, after experimenting with more conventional farming methods, the POFs could be characterised as having returned to the norms and values they had learned from their parents, and which felt more like how farming 'ought' to operate. This gave them the reassurance that their decision was understood and, importantly, approved by the previous generation (Lähdesmäki and Matilainen, 2014)and so did not cause confusion, surprise or rifts within the family. The attitudes of family members, particularly those who previously farmed the land, were important in shaping the conversion experiences of the organic farmers. However, while negative impressions presented a potential challenge to the continuation of an organic farm through loss of credibility or family disagreements over how to run a 'good' farm, it is important to separate 'organic' from 'farm'. Anti-organic sentiments may hinder the continuation of organic production but these do not necessarily also impact on the resilience of the farm.

\subsection{Market Innovations}

Although Padel (2001) notes that, among early adopters, husbandry-related as opposed to financial concerns appear more frequently as conversion motivations, our research suggested that POFs were more oriented towards commercial than subsistence farming. Indeed, in Finland in the 1970s and 1980s, converting to organics could be positioned as an enforced step towards a more entrepreneurial business model. It was common amongst our POFs, prior to their conversion, to be reliant on only one, large purchaser; in contrast, engaging in organic methods meant a diversification of distribution channels and clientele. This changing 
farm economy enforced innovation, which led to the creation of alternative retail spaces such as farm shops, which were rare at the time amongst conventional farmers, and farmers' markets. The latter were often used as distribution channels by the POFs as they presented a good opportunity to find customers for their novel products, who were often concentrated in larger urban areas. While this introduced challenges in terms of marketing, time, effort and capital, our POFs positioned the (re)connection with their consumers, alongside their sense of personal responsibility for addressing the challenges of organic farming, as important coping mechanisms in actually overcoming the various social, economic and cultural issues they experienced. For some, the transformation from conventional producer to the more entrepreneurial mind-set demanded of an organic producer at this time was particularly marked. Indeed, one POF argued that diversification and active engagement with consumers had been key to his organic farm's survival over the years:

'We always thought how to make the farm more profitable and then we came up with the idea of a home bakery. It [conversion to organic farming] enabled the opportunity to further process the products and we established a home bakery on our farm. After that, instead of just selling grains, we started to sell bread [...] Soon we had a rather large and permanent clientele. And the interaction with the consumers was very intense. They sometimes helped us with the harvest and everything and reciprocally, we organized farm fest, for example, we had Midsummer and harvest fest' (POF B)

It must be acknowledged that for many POFs these 'opportunities' for innovation and business autonomy were forced upon them, with few being motivated to convert because of these perceived benefits. Having such autonomy, particularly after a dependent, but safe, relationship with a buyer could be difficult, with the farmer having to move beyond a purely productive role and take responsibility for finding clientele. Many of our POFs recalled the difficulties they faced in the 1980s when the Finnish food processing industry had little interest in the niche, organic market and no desire to pay a premium for such produce. Retailers had similar attitudes and so many POFs had to rely on the alternative routes to market detailed above. These challenges in terms of marketing and selling organic commodities suggest that economic motivations were seldom central to POFs decision to convert to, and remain, organic.

In contrast, the recent converts were predominantly motivated to become organic in response to the increasing profitability challenges in agriculture (see Darnhofer et al., 2005, Ilbery et al., 2016). Unlike their predecessors, the economic rationality of the conversion decision outweighed other considerations, with their discussions centred on the high price of chemical inputs, decreasing producer prices for conventional produce and organic subsidies. Therefore, they positioned their commitment to organic production as pragmatic, in the sense that any reduction in its profitability would make them reconsider their choice: 
'Eventually I felt that I didn't get any profit from the yield I sold and there was no point in buying ridiculously expensive fertilizers anymore. So I came to the conclusion that I should try organic farming since it might provide better chances for economic viability. I didn't have any particular expectations towards organic farming; I just wanted to achieve a better economic result when compared with conventional farming' (COF H)

Admittedly, the COFs were appreciative of the environmental aspects and benefits of their now organic systems but they were keen to portray their conversion as a rational business decision, with no ideological underpinnings. In the interviews different types of 'organic farmer' emerged, with the COFs being careful to distinguish themselves from the stereotype of small-scale and unprofessional production by emphasizing the cost-effectiveness and modernity of their contemporary organic practices. As they grounded and legitimated their conversion in the language of a rational, economic choice -which retains hegemonic currency in Finnish agricultural discussions -in contrast to the POFs they were not ostracized by their local farming communities but, instead, received support, encouragement and general acceptance. This highlights how changed attitudes towards organic production within the general farming community, and recognition of it as a business opportunity (Sutherland, 2013, Siltaoja et al., 2015), have shaped both its acceptability and motivations for participation.

Finally, even though some COFs used the conversion to organic agriculture as a chance to create connections to consumers and identify new distribution channels for their produce, the majority of the interviewees did not consider this necessary or even possible. This is partly due to changes at the industry level because there is an increasing need for organic produce in the food processing sector, and so farmers are able to use the same distribution channels as they used when farming conventionally. Furthermore, as farm sizes have increased (with the average size for an organic farm now 50.9 ha), farmers have neither the time nor the energy to diversify their marketing and retailing. Therefore, even though farm shops and direct sales have increased in popularity amongst Finnish consumers, many of the COFs considered these as too laborious and small-scale:

'I admit that the idea of selling meat direct from the farm to consumers is a charming one. Especially when you know that the meat you produce is of top quality. But then I also realize that I don't have energy for that, it would require so much extra work' (COF G)

While POFs highlighted the benefits of engaging innovatively with consumers and having diverse routes to market in terms of their farming resilience, the loss of this capacity does not necessarily imply increased vulnerability for the COFs. The usage of mainstream distribution channels reduces the entrepreneurial burden experienced by the POFs and is a positive indicator of growing public awareness of, and interest in, organics. Changes in the routes to market available to organic farms demonstrate the 
variations in, and contextuality of, the relations that support the continuation of these production spaces.

\section{Changing Contexts and Fluid Subjectivities in Farming Resilience}

Considering some of the strategies that have promoted resilience in these farm spaces has provided an interesting opportunity to take a contingent and open-ended engagement with commercial organic agriculture. Echoing Campbell and Rosin's (2011)study, speaking with both POFs and COFs undermined the entrenched bifurcation discourse present in many literatures on organic production. While we are not denying the differences between the producer groupings, we argue that the intra-group differences and inter-group commonalities uncovered in terms of economic innovation, governance and social capital present a rather more nuanced perspective. Organics is a heterogenous sector and our contextual exploration of farming resilience highlights both the complex and relational nature of farm-level dynamics, and that organics has always been a contingent arena of continual negotiation (Rosin and Campbell, 2009, Darnhofer et al., 2016). Farming is 'a work in progress' (Riley, 2011: 17)and how different POFs and COFs engaged with and were shaped by, for example, each other, family, institutions and markets highlights the variety and dynamism of such relations, which have moreover always been grounded within (more or less) distanciated networks of interaction.

Each of these farms is still active and the empirics demonstrate the multiplicity of actants, relations, materialities and practices that have, and continue to, produce them as working farms. Relations with other farmers, organic advisors, regulators, paperwork, family members, farmers' markets and the values of autonomy, 'good' farming, being 'environmental' and economic viability all work together in myriad ways to connect and compose these farm places. Where the producers had the capability to choose, they were fundamentally strategic, with the main objective being to maintain the farm. Economic entrepreneurship allowed the POFs to develop and foster new market relations that enabled them to reach interested consumers, bypassing conventional distribution channels. Critically, the pragmatic motivations of COFs, but also expressed by some of the POFs, are about the continuation of the farm as a producing space, which arguably demonstrates a degree of separation and reflexivity between identifying as a producer and specifically as an organic producer.

We can see that there have been cultural shifts that shape how these organic farms are resilient; to paraphrase Ilbery et al (2016), over time different factors coalesce in particular ways in specific regions to shape who produces organically, why and how. Since the 1990sthe sector as a whole in Finland has become more regulated, with a particular model of organics becoming normalised through standardised production techniques and certification criteria. While the initial, uncharted terrain of organics presented 
socio-economic and political challenges to the POFs, the opportunities in terms of shaping the concept and an enforced drive for innovation, experiential learning and connecting beyond their common experiences of localised isolation undoubtedly played a key role in affirming organic production through shared knowledges, mutual support and ideological passion in the face of hegemonic disapproval. Having to fight and innovate in order to survive developed the broader, co-constitutive relations between the POFs, their farms, livestock, crops, machines, consumers, networked communities and the organic discourse, which we argue helped create and maintain a resilient organic system. Grappling with the increased regulation and bureaucratisation of organics presents a challenge to maintaining the organic farm that did not exist in the early days, although given the paperwork and regulators that all farms have to engage with, this arguably does not just present an issue for the organic farm. Nonetheless, while the initial opportunities to innovate and engage with governance may have faded, COFs now have more governmental support through grants and subsidies, expert advice, a greater variety of learning opportunities and increasingly intensified local collaboration. Farming resilience is clearly variable, and the changing institutional environment demonstrates how critical the spatial and temporal contexts of production are in governing how it is possible for farms to continue.

Discussions with producers also suggest a shift in the culture of organics with COFs keen to separate themselves from the lingering, often negative, stereotypes that are still attached to organic farming. Therefore, the discourse of an explicitly economically motivated, 'rational' organic producer has emerged. Many of the POFs have reached retirement age and so this suggests that the more idealistic attitudes and ambitions that initially gave the movement such dynamism are being lost. However, this separation, particularly espoused by the COFs, perpetuates the idea of a bifurcation in the movement, when in fact we argue that organics is better understood as composed of, and performed by, fluid and hybrid subjectivities. The identification of 'idealist' and 'pragmatist' producers emerges as essentialising binaries that do not reflect the reality of fluctuating and mixed practices and identities that are more dependent on the changeable demands of particular contexts. For example, POFs were not always or solely motivated by ideals of environmental care and health, considerations of profitability and economic viability were also present; similarly, COFs were not always or solely 'pragmatic'. Such subjectivities are always performed through the constant and complex interplay between the different elements that order the farm (Holloway, 2002, Holloway and Morris, 2014). Where then does this leave farming resilience? The fluctuating and hybrid subjectivities of the farmer; the changing organic cultures; the multiple elements that compose the farm and which all have differing capabilities to be vulnerable or resilient at any given moment; and the variety of relations that, in different times and spaces, support the ongoing praxis of the farm as a farm, all point to its fundamental contextuality and plurality, which is grounded in a diverse and evolving sector. 


\section{Conclusions}

Finnish organic producers have engaged in a variety of strategies and relations that, to date, have ensured the continuation of their farms. Drawing on the concept of farming resilience we explored these experiences at the farm-level, positioning resilience as the relational processes through which a farm remains a farm; our lack of a normative privileging of particular structures, performances or outcomes left space for practices of both continuity and change. Through exploring the dynamic, unfolding relations involved in building social capital, engaging with governance, working within family discourses of 'good farming' and developing market innovations, we challenged the continuing emphasis on the bifurcation of the movement, instead arguing for a fluid and hybrid subjectivity that is strategic and context dependent. Neither POFs nor COFs are homogenous or static in their mobilisation of norms, practices, relations or objects. Together with the variety of strategies highlighted across the times and spaces of these organic farms, this highlighted the contextuality and plurality of farming resilience, which was performed differently through each farm. As Anderson (2015: 61)argues 'there is not and never has been one resilient subject' and resilience has emerged here as always spatially and temporally various and uneven. Olsson et al (2015) criticise the universalising tendencies of more scientific resilience theories that endeavour to explain the social. As our discussion has shown, recognising resilience's plurality and emergence in relation to everyday unpredictabilities, such as state involvement, local attitudes and retailer preferences, rather than just catastrophes (Anderson, 2015) better contextualises the concept within the on-the-ground experiences and performances of society.

Here, organics itself has emerged as an overarching resilience strategy for farming with producers engaging with it as long as it enhances their economic and environmental viability. Who then is farming resilience for? Who benefits? In organic systems such as these arguably, amongst others, animals benefit from higher welfare standards, workers and soils benefit from changed chemical usage, farmers benefit from higher market prices while regulators benefit from the influx of certification fees. Although we positioned the farm as the scale of analysis, it is clear that the relations and strategies involved in the resilient farm go beyond its physical boundaries. While focusing here on organic, agricultural systems, the debates in this paper have broader relevance, connecting into contemporary, theoretical discussions around the nature and practice of resilience (Adgerand Nelson, 2010, Bourbeau, 2015, Fainstein, 2015, Levine et al., 2012)and applicability to conventional production systems. Although different in focus and values, relations with the market, family, governance institutions and other producers, amongst others, are arguably equally important in governing the performative strategies that promote or hinder farming resilience. After all, it is not only organic producers who have fluid and hybrid subjectivities that 
support their farms in becoming resilient, although we suggest that conventional producers' experiences will be qualitatively different.

Finally, the discussion of farming resilience as contextual and plural has policy implications. Understanding how farms are actually resilient, and further research on the role of dynamic non-human actants, power relations and in conventional systems, is crucial to the enactment of effective strategies to deal with the ongoing and, in some cases, worsening global uncertainty in terms of the health of humans, plants and animals, the economy and global environmental change.

\section{Acknowledgements}

We would like to thank all who participated in the study, and the second and third authors would like to acknowledge the financial support of the Academy of Finland (grants 260138 and 259482). We would also like to thank Liz Roberts, Mara Miele, colleagues at the Ruralia Institute and the anonymous reviewers for their constructive comments.

\section{References}

ADGER, W. N. 2000. Social and Ecological Resilience: are they related? Progress in Human Geography, 23,347364.

ADGER, W. N. \& NELSON, D. 2010. Fair decision making in a new climate of risk. In: O'BRIEN, K., ST. CLAIR, A. \& KRISTOFFERSEN, B. (eds.) Climate Change, Ethics and Human Security. Cambridge: Cambridge University Press.

AHNSTRÖM, J., HOCKERT, J., BERGEA, H. L., FRANCIS, C. A., SKELTON, P. \& HALLGREN, L. 2008. Farmers and Nature Conservation: what is known about attitudes, context factors and actions affecting conservation? Renewable Agriculture and Food Systems, 24, 38-47.

ALDRICH, D. P. \& MEYER, M. A. 2015. Social Capital and Community Resilience. American Behavioral Scientist, 59,254-269.

ANDERSON, B. 2015. What Kind of Thing is Resilience? Politics, 35, 60-66.

BERKES, F. \& ROSS, H. 2013. Community Resilience: towards an integrated approach. Society and Natural Resources, 26, 5-20.

BERRY, H., HOGAN, A., OWEN, J., RICKWOOD, D. \& FRAGAR, L. 2011. Climate Change and Farmers' Mental Health: risks and responses. Asia-Pacific Journal of Public Health, 23,119S-132S. 
BJORKHUAG, H. \& BLEKESAUNE, A. 2013. Development of Organic Farming in Norway: a statistical analysis of neighbourhood effects. Geoforum, 45,201-210.

BJÖRKLUND, J., ARAYA, H., EDWARDS, S., GONCALVES, A., HÖÖK, K., LUNDBERG, J. \& MEDINA, C. 2012. Ecosystem-Based Agriculture Combining Production and Conservation -a viable way to feed the world in the long term? Journal of Sustainable Agriculture, 36,824-855.

BOURBEAU, P. 2015. Resilience and International Politics: premises, debates, agenda. International Studies Review.

BRASSETT, J., CROFT, S. \& VAUGHAN-WILLIAMS, N. 2013. Introduction: an agenda for resilience research in politics and international relations. Politics, 33,221-228.

BUCIEGA, A., PITARCH, M.-D. \& ESPARCIA, J. 2009. The Context of Rural-Urban Relationships in Finland, France, Hungary, the Netherlands and Spain. Journal of Environmental Policy \& Planning, 11, 9-27.

BURTON, R. J. F. 2004. Seeing through the 'Good Farmer's' Eyes: towards developing an understanding of the social symbolic value of 'productivist' behaviour. Sociologia Ruralis, 44,195-215.

CAMPBELL, H. \& ROSIN, C. 2011. After the 'Organic Industrial Complex': an ontological expedition through commercial organic agriculture in New Zealand. Journal of Rural Studies, 27,350-361.

CLARKE, N., CLOKE, P., BARNETT, C. \& MALPASS, A. 2008. The Spaces and Ethics of Organic Food. Journal of Rural Studies, 24,219-230.

CLEAVER, F. \& FRANKS, T. 2005. How institutions elude design: River basin management and sustainable livelihoods: Bradford Centre for International Development, University of Bradford.

COTE, M. \& NIGHTINGALE, A. J. 2012. Resilience Thinking Meets Social Theory: situating social change in socio-ecological systems (SES) research. Progress in Human Geography, 36,475-489

COWARD, M. 2015. Editor's Introduction: resilience revisited. Politics, 35, 58-59.

CURRY, N., INGRAM, J., KIRWAN, J. \& MAYE, D. 2012. Knowledge Networks for Sustainable Agriculture in England. Outlook on Agriculture, 41,243-248.

CUTHILL, M., ROSS, H., MACLEAN, K., OWENS, K. \& WITT, B. 2008. Reporting Social Outcomes of Development: an analysis of diverse approaches. The International Journal of Interdisciplinary Social Science, 3,145-158.

DALE, A., LING, C. \& NEWMAN, L. 2008. Does Place Matter? Sustainable Community Development in Three Canadian Communities. Ethics, Place \& Environment, 11,267-281. 
DARNHOFER, I. 2014. Resilience and why it Matters for Farm Management. European Review of Agricultural Economics, 41,461-484.

DARNHOFER, I., FAIRWEATHER, J. \& MOLLER, H. 2010. Assessing a Farm's Sustainability: insights from resilience thinking. International Journal of Agricultural Sustainability, 8,186-198.

DARNHOFER, I., LAMINE, C., STRAUSS, A. \& NAVARRETE, M. 2016. The Resilience of Family Farms: towards a relational approach. Journal of Rural Studies, 44,111-122.

DARNHOFER, I., SCHNEEBERGER, W. \& FREYER, B. 2005. Converting or not converting to organic farming in Austria: Farmer types and their rationale. Agriculture and Human Values, 22, 39-52.

DIPROSE, K. 2014. Resilience is Futile: the cultivation of resilience is not an answer to austerity and poverty. Soundings, 44-56.

DOUGLAS, M. 2002. Purity and Danger: an analysis of concept of pollution and taboo. London, Routledge.

DURAM, L. A. 1999. Factors in Organic Farmers' Decision-making: diversity, challenge, and obstacles. American Journal of Alternative Agriculture, 14, 2-10.

DURAM, L. A. 2005. Good Growing: why organic farming works, Lincoln, NE, University of Nebraska Press.

DWIARTAMA, A. \& ROSIN, C. 2014. Exploring Agency Beyong Humans: the compatibility of Actor-Network Theory (ANT) and resilience thinking. Ecology and Society, 19, 28.

ELMS, D. 2015. Improving Community Resilience to Natural Events. Civil Engineering and Environmental Systems, 32, 77-89.

EUROSTAT. 2013. Agricultural Census in Finland [Online]. Available: http://ec.europa.eu/eurostat/statisticsexplained/index.php/Agricultural_census_in_Finland\#Agricultural_holdings[Accessed 21 February 2017].

EVIRA. 2014. Luomutilat ja luomutuotantoala. [Organic farms and organically cultivated farm area in Finland] [Online]. Available:.

http://www.evira.fi/files/attachments/fi/evira/asiakokonaisuudet/luomu/tilastot/luomu_2014ep.pdf[Acces sed 18 March 2016].

FAINSTEIN, S. 2015. Resilience and Justice. International Journal of Urban and Regional Research, 39,157167.

FOLKE, C., COLDLING, J. \& BERKES, F. 2003. Synthesis: building resilience and adaptive capacity in socialecological systems. In: BERKES, F., COLDLING, J. \& FOLKE, C. (eds.) Navigating Social-Ecological Systems: building resilience for complexity and change. Cambridge: Cambridge University Press. 
FORNEY, J. \& STOCK, P. V. 2014. Conversions of Family Farms and Resilience in Southland, New Zealand. International Journal of the Sociology of Agriculture and Food, 21, 7-29.

FOUILLEUX, E. \& LOCANTO, A. 2017. Voluntary Standards, Certification, and Accreditation in the Global Organic Agriculture Field: a tripartitie model of techno-politics. Agriculture and Human Values, 34,1-14.

FRASER, C. E., SMITH, K. B., JUDD, F., HUMPHREYS, J. S., FRAGAR, L. J. \& HENDERSON, A. 2005. Farming and Mental Health Problems and Mental Illness. International Journal of Social Psychiatry, 51,340-349.

GIBSON-GRAHAM, J. K. 2008. Diverse Economies: performative practices for 'other worlds'. Progress in Human Geography, 32,613-632.

GRAY, J. 1996. Cultivating Farm Life on the Borders: Scottish hill sheep farms and the European community. Sociologia Ruralis, 36, 27-50.

GREENHILL, J., KING, D., LANE, A. \& MACDOUGALL, C. 2009. Understanding Resilience in South Australian Farm Families. Rural Society, 19,318-325.

GUTHMAN, J. 2004. The Trouble with 'Organic Life' in California: a rejoinder to the 'conventionalisation' debate. Sociologia Ruralis, 44 .

HALBERG, N., ALROE, H. F. \& KRISTENSEN, E. S. 2006. Synthesis: prospects for organic agriculture in a global context. In: HALBERG, N., ALROE, H. F., KNUDSEN, M. T. \& KRISTENSEN, E. S. (eds.) Global Development of Organic Agriculture: challenges and prospects. Wallingford: CABI Publishing.

HAMMOND, B., BERARDI, G. \& GREEN, R. 2013. Resilience in Agriculture: small-and medium-sized farms in Northwest Washington State. Agroecology and Sustainable Food Systems, 37,316-339.

HANSSON, H. \& LAGERKVIST, C. J. 2012. Measuring Farmers' Attitudes to Animal Welfare and Health. British Food Journal, 114,840-852.

HEINONEN, S. 2004. Luonnonmukainen maatalous. [Organic Agriculture]. In: MARKKOLA, P. (ed.) Suomenmaatalouden historia III: Suurten muutosten aika -Jälleenrakennuskaudesta EU-Suomeen. Helsinki: Finnish Literature Society.

HERMAN, A. 2016. 'More-than-human' Resilience(s)? Enhancing Community in Finnish Agriculture. Geoforum, 69, 34-43.

HOLLOWAY, L. 2002. Smallholding, hobby-farming, and commercial farming: ethical identities and production of farming spaces. Environment and Planning A, 34, 2055-2070.

HOLLOWAY, L. \& MORRIS, C. 2014. Viewing Animal Bodies: truths, practical aesthetics and ethical considerability in UK livestock breeding. Social \& Cultural Geography, 15, 1-22. 
HOWELL, A. 2015. Resilience as Enhancement: governmentality and political economy beyond 'responsibilisation'. Politics, 35, 67-71.

HUNT, W., VANCLAY, F., BIRCH, C., COUTTS, J., FLITTNER, N. \& WILLIAMS, B. 2011. Agricultural Extension: building capacity and resilience in rural industries and communities. Rural Society, 20,112-127.

IANCU, A. 2012. The Challenges of Rural Development in Europe. Economics, Management, and Financial Markets, 7,239-244.

ILBERY, B., KIRWAN, J. \& MAYE, D. 2016. Explaining Regional and Local Differences in Organic Farming in England and Wales: a comparison of South West Wales and South East England. Regional Studies, 50,110123.

INGRAM, J., MAYE, D., KIRWAN, J., CURRY, N. \& KUBINAKOVA, K. 2015. Interactions between Niche and Regime: an analysis of learning and innovation networks for sustainable agriculture across Europe. The Journal of Agricultural Education and Extension, 21, 55-71.

KALLINEN, A., HEIKKILÄ, A., HEIKKILÄ, E., PETHMAN, P. \& PIRTTIJÄRVI, R. 2012. Luomutuotannon kehitysnäkymät 2020 [The development trends of organic agriculture 2020] Elintarviketieto Oy: Suomen Gallup.

KOMINO, T. 2014. Community Resilience: why it matters and what we can do. The Ecumenical Review, 324329.

KOTTILA, M.-R. \& RÖNNI, P. 2008. Collaboration and Trust in Two Organic Food Chains. British Food Journal, $110,376-394$.

KRøVEL, R. 2014. Social Production of Community Resilience. Resilience: International Policies, Practices and Discourses, 2, 64-70.

KUMM, K.-I. 2002. Sustainability of Organic Meat Production under Swedish Conditions. Agriculture, Ecosystems and Environment, 88, 95-101.

KUMMER, S., MILESTAD, R., LEITGEB, F. \& VOGL, C. R. 2012. Building Resilience through Farmers' Experiments in Organic Agriculture: examples from eastern Austria. Sustainable Agriculture Research, 1,308-321.

LÄHDESMÄKI, M. \& MATILAINEN, A. 2014. Born to be a forest owner? An empirical study of the aspects of psychological ownership in the context of inherited forests in Finland. Scandinavian Journal of Forest Research, 29,101-110.

LÄPPLE, D. \& VAN RENSBURG, T. 2011. Adoption of Organic Farming: are there differences between early and late adoption? Ecological Economics, 70, 1406-1414. 
LEGARD, R., KEEGAN, J. \& WARD, K. 2003. In-depth Interviews. In: RITCHIE, J. \& LEWIS, J. (eds.) Qualitative Research Practice: a guide for social science students and researchers. Thousand Oaks, CA: Sage Publications Ltd.

LEVINE, S., PAIN, A., BAILEY, S. \& FAN, L. 2012. The Relevance of 'Resilience'. HPG Policy Brief. Humanitarian Policy Group.

LIN, B. B. 2011. Resilience in Agriculture through Crop Diversification: adaptive management for environmental change. BioScience, 61,183-193.

LOBLEY, M., BUTLER, A. \& WINTER, M. 2013. Local Organic Food for Local People? Organic Marketing Strategies in England and Wales. Regional Studies, 47,216-228.

MACLEAN, K., CUTHILL, M. \& ROSS, H. 2014. Six Attributes of Social Resilience. Journal of Environmental Planning and Management, 57,144-156.

MAGIS, K. 2010. Community Resilience: an indicator of social sustainability. Society and Natural Resources, 23,401-416.

MALEKSAEIDI, H. \& KARAMI, E. 2013. Social-Ecological Resilience and Sustainable Agriculture under Water Scarcity. Agroecology and Sustainable Food Systems, 37,262-290.

MASON, G. \& PULVIRENTI, M. 2013. Former Refugees and Community Resilience: 'papering over' domestic violence. British Journal of Criminology, 53,401-418.

MCDONAGH, J. 2012. Rural Geography 1: changing expectations and contradictions in the rural. Progress in Human Geography, 1-9.

MICHELSEN, J. 2001. Recent Development and Political Acceptance of Organic Farming in Europe. Sociologia Ruralis, 41, 3-20.

MILES, M. \& HUBERMAN, M. 1994. Qualitative Data, London, Thousand Oaks: Sage Publications.

MILESTAD, R. \& DARNHOFER, I. 2003. Building Farm Resilience: the prospects and challenges of organic farming. Journal of Sustainable Agriculture, 22, 81-97.

MMM 2007. Food for Growth. Rural Development Programme for Mainland Finland 2007-2013.

MMM 2011. Action Plan for the Adaptation to Climate Change of the Ministry of Agriculture and Forestry 2011-2015: security of supply, sustainable competitiveness and risk management. Helsinki: MMM.

MONONEN, T. 2008. Luomun verkostot. Tutkimus suomalaisen luomutuotannon toimijaverkostojenmuutoksesta [Networks of organic production -Study on transformation in the Finnish organic production network]. Joensuu: Joensuun yliopistopaino. 
MORGAN, K. \& MURDOCH, J. 2000. Organic vs. Conventional Agriculture: knowledge, power and innovation in the food chain. Geoforum, 31,159-173.

NORRIS, F. H., STEVEnS, S. P., PfefferbaUM, B., WYCHE, K. F. \& PfefferbaUM., R. L. 2008. Community Resilience as a Metaphor, Theory, Set of Capabilities, and Strategy for Disaster Readiness. American Journal of Community Psychology, 41,127-150.

OLSSON, L., JERNECK, A., THOREN, H., PERSSON, J. \& O'BYRNE, D. 2015. Why Resilience is Unappealing to Social Science: theoretical and empirical investigations of the scientific use of resilience. Science Advances, 1, 1-11.

PADEL, S. 2001. Conversion to Organic Farming: a typical example of the diffusion of an innovation? Sociologia Ruralis, 41, 40-61.

PADEL, S. 2008. Values of Organic Producers Converting at Different Times: results of a focus group study in five European countries. International Journal of Agricultural Resources, Governance and Ecology, 7, 63-77. PATTON, M. Q. 2002. Qualitative Research \& Evaluation Methods, London, Sage Publications.

PERRINGS, C. 1998. Introduction: resilience and sustainable development. Environment and Development Economics, 3,221-262.

PYYSIÄINEN, J. 2011. Constructing and Negotiating Entrepreneurial Agency a Social Psychological Approach to Entrepreneurship Discourse in the Farm Context. University of Helsinki.

RANJAN, R. 2014. Multi-Dimensional Resilience in Water-Scarce Agriculture. Journal of Natural Resources Policy Research, 6,151-172.

RANTALA, O. \& TAURIAINEN, J. 2015. The Economic Situation of Agriculture. In: NIEMI, J. \& AHLSTEADT, J. (eds.) Finnish Agriculture and Rural Industries 2015. Helsinki: Natural Resources Institute Finland.

REIMER, A. P., THOMPSON, A. W. \& PROKOPY, L. S. 2012. The Multi-Dimensional Nature of Environmental Attitudes among Farmers in Indiana: implications for conservation adoption. Agriculture and Human Values, 29, 29-40.

RIGBY, D., YOUNG, T. \& BURTON, M. 2001. The Development of and Prospects for Organic Farming in the UK. Food Policy, 26,599-613.

RILEY, M. 2011. 'Letting Them Go'-Agricultural Retirement and Human-Livestock Relations. Geoforum, 42, 16-27.

ROSENTHAL, G. 1993. Reconstruction of life stories: principles of selection in generating stories for narrative biographical interviews. In: JOSSELSON, R. \& LIEBLICH, A. (eds.) the Narrative Study of Lives. Newbury Park, CA: Sage. 
ROSIN, C. \& CAMPBELL, H. 2009. Beyond Bifurcation: examining the conventions of organic agriculture in New Zealand. Journal of Rural Studies, 25, 35-47.

SCHNEEBERGER, W., DARNHOFER, I. \& EDER, M. 2002. Barriers to the Adaption of Organic Farming by CashCrop Producers in Austria. American Journal of Alternative Agriculture, 17, 24-31.

SGPFS 2010. Food for Tomorrow: proposal for Finland's National Food Strategy. Steering Group for the Preparation of the Food Strategy.

SILTAOJA, M., LÄHDESMÄKI, M., PUSKA, P., KURKI, S. \& LUOMALA, H. 2015. From Shame to Fame: A Model of the Destigmatization Process in Media Discourse. Academy of Management Proceedings.

SILVASTI, T. 2003a. The Cultural Model of 'The Good Farmer' and the Environmental Question in Finland. Agriculture and Human Values, 20,143-150.

SILVASTI, T. 2003b. Bending Borders of Gendered Labour Division on Farms: the case of Finland. Sociologia Ruralis, 43,154-166.

STOCK, P. V. 2007a. 'Good Farmers' as Reflective Producers: an examination of family organic farmers in the US Midwest. Sociologia Ruralis, 47, 83-102.

STOCK, P. V. 2007b. Good farmers' as reflexive producers: An examination of family organic farmers in the US Midwest. Sociologia Ruralis, 47, 83-102.

SUTHERLAND, L.-A. 2013. Can Organic Farmers be 'Good Farmers'? Adding the 'Taste of Necessity' to the Conventionalization Debate. Agriculture and Human Values, 30,429-441.

USCHER-PINES, L., CHANDRA, A. \& ACOSTA, J. 2013. Commentary: the promise and pitfalls of community resilience. Disaster Medicine and Public Health Preparedness, 7,603-606.

VALANTE, T. W. 1996. Social Network Thresholds in the Diffusion of Innovations. Social Networks, 18, 69-89. VÄRE, M. 2015. Finnish Farm. In: NIEMI, J. \& AHLSTEADT, J. (eds.) Finnish Agriculture and Rural Industries 2015. .Helsinki: Natural Resources Institute Finland.

VESALA, H. T. \& VESALA, K. M. 2010. Entrepreneurs and producers: Identities of Finnish farmers in 2001 and 2006. Journal of Rural Studies, 26, 21-30.

VESALA, K. M. \& PEURA, J. 2005. Presentation of personal control in the rhetoric of farm families engaged in business diversification in Finland. Journal of Comparative Family Studies, 36,443-473.

VOGL, C. R., KILCHER, L. \& SCHMIDT, H. 2005. Are Standards and Regulations of Organic Farming Moving Away from Small Farmers' Knowledge? Journal of Sustainable Agriculture, 26, 5-26. 
WAGNER, I. \& WODAK, R. 2006. Performing success: identifying strategies of self-presentation in women's biographical narratives. Discourse \& Society, 17,385-411.

WILSON, G. A. 2015. Community Resilience and Social Memory. Environmental Values, 24,227-257.

YLIVIIKARI, A. 2016. Kokeilun kipinöistä leviävät murrokset: Case luomutuotannon kehitys Suomessa

[Experimentation leads to changes: The case of the development of organic production in Finland]. Alue ja Ympäristö, 45, 75-82. 